\begin{tabular}{|l|l|} 
Jurnal Bimbingan dan Konseling Ar-Rahman \\
Volume 5, Nomor 2, Tahun 2019 \\
Tersedia Online: http://ojs.uniska.ac.id/index.php/BKA \\
e-ISSN 2477-6300
\end{tabular}

\title{
HUBUNGAN KETERLIBATAN SISWA DENGAN KENAKALAN REMAJA PADA SISWA SMA X KERTAPATI
}

\author{
Juliani Dwi Putri, Indra Prapto Nugroho, Marisya Pratiwi \\ Program Studi Psikologi Fakultas Kedokteran Universitas Sriwijaya \\ E-mail: ipnugroho@fk.unsri.ac.id
}

\begin{abstract}
ABSTRAK
Tujuan dari penelitian ini adalah untuk mengetahui bagaimana hubungan antara keterlibatan siswa dengan kenakalan remaja pada siswa SMA X Kertapati. Hipotesis yang diajukan dalam penelitian ini ada hubungan antara keterlibatan siswa dengan kenakalan remaja pada siswa SMA X Kertapati. Adapun subjek penelitian yang digunakan ialah siswa SMA X Kertapati berjumlah 205 orang. Keterlibatan siswa dan kenakalan remaja diukur dengan skala keterlibatan siswa dan kenakalan remaja berlandaskan aspek keterlibatan siswa dari Fredericks, Blumenfeld dan Paris (2004) dan aspek kenakalan remaja dari Sarwono (2016). Data penelitian dianalisis dengan menggunakan metode korelasi Spearman. Hasil penelitian menunjukkan ada hubungan antara keterlibatan siswa dengan kenakalan remaja pada siswa SMA X Kertapati dengan nilai $r=-0,727$, dan $p=0,000(p<0,05)$. Hal ini menunjukkan bahwa keterlibatan siswa memiliki hubungan yang sangat kuat, negatif, dan signifikan dengan kenakalan remaja. Dengan demikian hipotesis penelitian yang diajukan dapat di terima.
\end{abstract}

Kata Kunci:Kenakalan Remaja; Keterlibatan Siswa; Remaja

\section{ABSTRACT}

The purpose of this study was to determine how the relationship between student involvement with juvenile delinquency in X Kertapati High School students. The hypothesis proposed in this study there is a relationship between student involvement with juvenile delinquency in high school students $X$ Kertapati. The research subjects used were high school students X Kertapati totaling 205 people. Student involvement and juvenile delinquency are measured by the scale of student involvement and juvenile delinquency based on aspects of student involvement from Fredericks, Blumenfeld and Paris (2004) and aspects of juvenile delinquency from Sarwono (2016). The research data were analyzed using the Spearman correlation method. The results showed there was a relationship between student involvement with juvenile delinquency in X Kertapati High School students with a value of $r=-0.727$, and $p=0,000(p<0.05)$. This shows that student involvement has a very strong, negative, and significant relationship with juvenile delinquency. Thus the research hypothesis proposed can be accepted.

Keywords:Juvenile delinquency; Student Involvement; Teenager

Dipublikasikan Oleh :

UPT Publikasi dan Pengelolaan Jurnal

Universitas Islam Kalimantan Muhammad Arsyad Al-Banjari Banjarmasin 
Juliani Dwi Putri, Indra Prapto Nugroho, Marisya Pratiwi

Jurnal Bimbingan dan Konseling Ar-Rahman

Volume 5, Nomor 2, Tahun 2019

e-ISSN 2477-6300

\section{PENDAHULUAN}

Masa remaja (adolescence) adalah masa pencarian jati diri, dimana pada masa ini remaja mulai mengeksplorasi semua hal baru untuk menemukan dunia yang sesuai dengan dirinya (Santrock, 2012). Masa remaja juga sering diiringi dengan keinginan untuk mengeksplorasi dan mencoba banyak hal yang ada di lingkungan sekitar. Perasaan ingin mencoba dan nilai-nilai yang negatif terkadang di adoposi oleh remaja untuk melakukan perbuatan yang tidak diharapkan oleh lingkungan yang seringkali disebut sebagai kenakalan remaja (Papalia, 2012).

Hasil laporan yang diterima oleh Komisi Nasional Perlindungan Anak mencatat bahwa di tahun 2018 tawuran yang di lakukan pelajar di Indonesia meningkat lebih tinggi jika di bandingkan pada tahun 2017 yaitu sebanyak 1,1 persen. Pada tahun 2017, angka kasus tawuran hanya 12,9 persen sementara tahun 2018 meningkat menjadi 14 persen kasus tawuran (Firmansyah, 2018). Kasus-kasus diatas menunjukkan perilaku yang menimbulkan korban fisik seperti yang di kemukakan oleh Sarwono (2006). Perilaku ini tergolong dalam aspek-aspek kenakalan remaja.

Semua tingkah laku yang menyimpang dari ketentuan yang sudah berlaku pada masyarakat di sebut kenakalan (Sarwono, 2016). Menurut Santrok (2003) istilah kenakalan remaja (juvenile delinquency) mengacu pada suatu rentang yang luas, dari tingkah laku yang tidak dapat di terima secara sosial (misalnya bersikap berlebihan di sekolah) sampai pelanggaran status (seperti melarikan diri) hingga tindak kriminal (misalnya pencurian).

Kartono (2015) menjabarkan istilah kenakalan dengan sebutan Juvenile Delinquency (juvenilis = muda, bersifat kemudaan; kenakalan dari "delinquare = jahat, durjana, pelanggar, nakal) ialah anak-anak muda yang selalu melakukan kejahatan, di maksudkan untuk mendapatkan perhatian, status sosial dan penghargaan dari lingkungannya. Kennedy (1963) menjelaskan bahwa kenakalan remaja adalah pemuda yang telah melakukan kejahatan atau percobaan pelanggaran norma. Menurut Bakwin (2015) istilah kenakalan remaja merujuk pada tindakan berulang yang di lakukan oleh remaja pada jenis pelanggaran yang dilakukan oleh orang dewasa yang di anggap sebagai kejahatan.

Chingtam (2015) menjelaskan penyebab kenakalan remaja adalah faktor pribadi (keturunan genetik, faktor fisik dan faktor mental); faktor sosial (kekuatan sosial dalam membentuk normadan nilainilai yang terkandung pada masyarakat); faktor keluarga (kondisi keluarga yang tidak harmonis, kemiskinan, orang tua yang cacat, pengajaran orang tua terhadap anak mengenai norma dan etika); faktor psikologis (subnormalitas mental, penyakit mental, ketidakseimbangan kepribadian, ketidakstabilan emosional); dan faktor akademis (suasana sekolah, kasus putus sekolah, ketidaktertarikan dalam kegiatan akademik, kelompok sebaya, ketidakpedulian guru terhadap siswa).

Senada dengan pendapat Bender (2012) bahwa tingkat kenakalan remaja yang lebih tinggi karena kurangnya keterlibatan siswa di sekolah. Remaja yang tidak pernah menyapa guru, tidak menyelesaikan tugas sekolah dan tidak mematuhi peraturan sekolah dapat menyebabkan meningkatnya kenakalan pada diri remaja tersebut. Menurut Wang dan Fredericks (2014) penurunan siswa untuk terlibat dalam sekolah dapat menuntun remaja pada peningkatan kenakalan dan penggunaan narkoba dari waktu ke waktu. Selain itu, studi memperkirakan sebanyak $40-60 \%$ remaja menunjukkan tanda-tanda kurangnya keterlibatan seperti sikap apatis, kurang berusaha, tidak mau terlibat dan tidak memperhatikan.

Definisi keterlibatan siswa telah di pelajari menggunakan berbagai istilah termasuk ikatan sekolah, keterhubungan sekolah, dukungan guru, iklim sekolah keterlibtan sekolah, dan keterlibatan siswa. Variasi-variasi tersebut menjelaskan tentang subkomponen dari keterlibatan termasuk konseptualisasi tentang keterlibatan itu sendiri (Gilman, Huebner \& Furlong, 2009).

Menurut Wang dan Holcombe (2010) remaja yang memiliki keterlibatan akan terlibat positif dalam aktifitas sekolahnya, baik itu meluangkan waktu untuk mengembangkan potensi akademis mereka, menyalurkan energi mereka pada kegiatan-kegiatan positif yang serta mengerahkan. Reeve dan Tseng (2011) mengemukakan keterlibatan siswa adalah keterlibatan yang memiliki empat aspek, yaitu agentic engagement,behavioral engagement, emotional engagement dan cognitive engagement. Chapman (2003) menjelaskan bahwa keterlibatan siswa (student engagement)didefinisikan sebagai "pengorbanan waktu dan energi siswa yang dicurahkan untuk kegiatan pendidikan yang sehat". Perilaku keterlibatan dalam hal ini adalah kesediaan untuk menyelesaikan tugas, menghadiri kelas, dan partisipasi dalam kegiatan sekolah.

Murray, Mitchell, dkk (2014) menyebutkan faktor-faktor yang menyebabkan siswa tidak mau terlibat dalam aktivitas sekolah adalah kurangnya keinginan untuk berprestasi pada siswa serta ketidakmampuan siswa untuk menyesuaikan diri pada aktivitas sekolah, guru yang kurang mampu untuk memahami perbedaan kemampuan dari masingmasing siswa dan penyampaian pembelajaran yang kurang tepat sehingga siswa merasa pelajaran tersebut membosankan bahkan terlalu sulit untuk mereka pahami.

Adapun rumusan masalah dalam penelitian ini adalah bagaimana hubungan antara keterlibatan siswa dengan kenakalan remaja pada siswa SMA X 
Kertapati. Kemudian tujuan dari penelitian ini adalah untuk mengetahui ada atau tidak adanyahubungan antara keterlibatan siswa dengan kenakalan remaja pada siswa SMA X Kertapati.

\section{METODE}

\section{Pendekatan Penelitian}

Model pendekatan yang diterapkan dalam penelitian ini adalah pendekatan penelitian kuantitatif denganteknik korelasi Spearman Rank.Teknik analisis data Spearman Rank dapat digunakan untuk mengetahui hubungan korelasi jika data statistik bersifat nonparametrik serta sebaran data penelitian tidak berdistribusi normal (Sugiyono, 2014).

\section{Subjek Penelitian}

Populasi pada penelitian ini adalah siswa SMA $\mathrm{X}$ di Kertapati yang berjumlah 500 Siswa.Berdasarkan tabel yang di kembangkan oleh Isaac dan Michael (Sugiyono, 2016) dengan tingkat kesalahan yang di tetapkan sebesar 5\% dan presisi atau sampel ketepatan sebesar 95\%, maka jumlah sampel yang di ambil untuk populasi siswa SMA X di Kertapati adalah sebanyak 205 siswa dengan jumlah laki-laki sebanyak 81 siswa dan perempuan sebanyak 124 siswa.Bentuk sampling yang digunakan adalah insidental sampling. Menurut Sugiyono (2016) insidental sampling adalah teknik penentuan sampel berdasarkan kebetulan, yaitu siapa saja yang secara kebetulan atau insidental bertemu dengan peneliti dapat digunakan sebagai sampel, bila dipandang orang yang kebetulan ditemui itu cocok sebagai sumber data.

\section{Variabel dan Instrumen Penelitian}

Dalam penelitian ini, metode pengumpulan data yang digunakan adalah menggunakan dua jenis skala yaitu skala kenakalan remaja dan skala keterlibatan siswa. Skala kenakalan remaja disusun oleh penelitidengan tingkat reliabilitas sebesar 0,948 dan didasarkan pada aspek-aspek kenakalan remaja menurut Sarwono (2006) yaitu perilaku yang menimbulkan korban fisik, korban materi, perilaku yang melanggar status, perilaku sosial yang tidak menimbulkan korban di pihak orang lain.Kemudian skala keterlibatan siswa juga disusun oleh peneliti berdasarkan aspek-aspek keterlibatan siswa oleh Fredericks, Blumenfeld dan Paris (2004), yang terdiri dari keterlibatan emosional, keterlibatan perilaku, dan keterlibatan kognitif dengan tingkat reliabilitas sebesar 0,884 .

\section{Analisa Data}

Metode analisa korelasi yang digunakan dalam penelitian ini ialah menggunakan teknik korelasi Spearman Rank dengan bantuanaplikasi perhitungan statistikSPSS versi 16.

\section{Hipotesis}

Hipotesis dalam penelitian ini ialah ada hubungan antara keterlibatan siswa dengan kenakalan remaja pada siswa SMA X Kertapati.

\section{HASIL DAN PEMBAHASAN}

Hasil penelitian yang ditunjukkan pada Tabel 1 berdasarkan analisis data yang diperoleh dari siswa SMA X Kertapati bahwa taraf signifikasi sebesar $0,000 \quad(p<0,05)$. Dengan demikian, hipotesa yang diajukan pada penelitian ini dapat diterima, yaitu ada hubungan antara keterlibatan siswa dengan kenakalan remaja pada siswa SMA X Kertapati.

Tabel 1. Uji Korelasi Rank Spearman

\begin{tabular}{lccccc}
\hline Variabel & $\boldsymbol{N}$ & Std.deviation & Mean & Spearman's rho & Sig \\
\hline Kenakalan Remaja & 205 & 14.23 & 42.31 & -.727 & 0.000 \\
Keterlibatan Siswa & 11.24 & 41.28 & & \\
\hline
\end{tabular}

Keterangan: Hasil analisis uji korelasi rank spearman

Hasil nilai koefisien korelasi pada analisis korelasi Spearmen Rankjuga didapatkan nilai r sebesar $-0,727$. Hasil ini menunjukkan kekuatan dan arah hubungan antara variabel bebas dan variabel terikat yang diukur. Keterlibatan siswadan kenakalan remaja pada penelitian ini berhubungan sangat kuat dan negatif. Artinya, semakin tinggi tingkat kenakalan remaja, maka tingkat keterlibatan siswa pada sekolah akan menurun. Sebaliknya, apabila tingkat kenakalan remaja menurun, maka tingkat keterlibatan siswa akan meningkat.Hal ini sejalan dengan penelitian yang dilakukan oleh Toldson, Sutton dan Brown (2012) bahwa untuk mengurangi perilaku kenakalan pada siswa dilakukan dengan cara meningkatkan keterlibatan siswa pada setiap proses kegiatan yang ada di sekolah.

Kemudian peneliti melakukan analisis data tambahan untuk melihat perbedaan kenakalan remaja dan keterlibatan siswa berdasarkan deskripsi subjek penelitian dan menemukan perbedaan kenakalan remaja berdasarkan jenis kelamin, kelas dan usia subjek. Berdasarkan hasil uji Mann-Whitney U Test, uji beda kenakalan remaja berdasarkan jenis kelamin mengahasilkan nilai signifikansi sebesar 0,000 $(p<0,05)$. Hal ini menunjukkan bahwa adanya 
perbedaan kenakalan remaja berdasarkan jenis kelamin subjek. Hasil mean menunjukkan subjek dengan jenis kelamin laki-laki $(122,49)$ lebih memiliki tingkat rata-rata kenakalan remaja yang lebih tinggi jika dibandingkan dengan perempuan $(90,27)$. Hal ini diperkuat juga dengan penelitian yang dilakukan oleh Harris-McKoy dan Cui (2012) bahwa perempuan dilaporkan memiliki tingkat kenakalan yang lebih rendah dari pada pria.

Selanjutnya uji beda keterlibatan siswa berdasarkan jenis kelamin juga menghasilkan nilai signifikan yaitu sebesar $0,000 \quad(p<0,05)$. Hal ini menunjukkan bahwa adanya perbedaan keterlibatan siswa berdasarkan jenis kelamin subjek. Hasil mean menunjukkan bahwa perempuan $(115,92)$ lebih banyak memiliki tingkat keterlibatan siswa jika dibandingkan dengan laki-laki (83,23).

Hal ini sejalan dengan hasil penelitian yang dilakukan oleh Daigle, Cullen dan Wright (2013) yang menunjukkan bahwa meskipun ada beberapa kesamaan dalam prediktor kenakalan laki-laki dan perempuan, namun dari hasil yang di dapatkan bahwa prediktor yang lebih kuat untuk kenakalan adalah lakilaki. Sedangkan keterlibatan pada dunia pendidikan lebih kuat untuk perempuan.

Selanjutnya, adapula perbedaan kenakalan remaja dan keterlibatan siswa berdasarkan kelas subjek. Pada kenakalan remaja berdasarkan usia subjek nilai signifikan yang di dapatkan adalah 0,000 $(\mathrm{p}<0,05)$ dan pada keterlibatan siswa berdasarkan kelas subjek juga memiliki nilai signifikan yaitu 0,000 $(\mathrm{p}<0,05)$. Artinya terdapat perbedaan antara variabel kenakalan remaja dan variabel keterlibatan siswa dengan perbedaan kelas subjek.

Hasil mean yang di dapatkan dari kenalan remaja berdasarkan perbedaan kelas yaitu 81,41 untuk kelas X dan 119,24 untuk kelas XI. Artinya, subjek kelas XI lebih memiliki tingkat kenakalan yang lebih tinggi dibandingkan subjek kelas X. Hasil analisis mean selanjutnya yang di dapatkandari keterlibatan siswa berdasarkan perbedaan kelas adalah 119,94 pada subjek kelas X dan 90,26 pada subjek kelas XI yang berarti bahwa subjek kelas $\mathrm{X}$ lebih memiliki keterlibatan siswa yang tinggi dibandingkan dengan subjek kelas XI.

Hasil analisis uji beda pada kenakalan remaja berdasarkan usia juga mendapatkan perbedaan yang signifikan yaitu $0,005(\mathrm{p}<0,05)$ yang berarti bahwa terdapat perbedaan kenakalan remaja berdasarkan usia subjek dengan nilai mean yang di dapatkan yaitu pada usia 16 tahun sebesar 115,01, usia 14 tahun sebesar 37,75 , usia 15 tahun sebesar78,60, usia 17 tahun sebesar 106,18dan usia 18 tahun sebesar 100,50.

Hal ini menunjukkan bahwa kenakalan remaja banyak didominasi oleh subjek yang berusia 16 tahun dan 17 tahun dari pada subjek yang berusia 14, 15 dan 18 tahun. Hasil tersebut sejalan dengan penelitian dari
Nourollah, Fatemeh dan Farhad (2015) yang menunjukkan bahwa 62\% dari subjek yang berada pada tahanan di Taheran karena terlibat pada kasus pelanggarandan berada pada usia remaja yaitu 16 hingga 18 tahun dan diantaranya $80 \%$ adalah laki-laki dan $20 \%$ perempuan.

\section{PENUTUP}

Berdasarkan hasil analisis data penelitian dan pembahasan yang telah dijabarkan, maka peneliti dapat menarik kesimpulan bahwa ada hubungan antara kenakalan remaja dengan keterlibatan siswa. Penelitian ini dapat digunakan sebagai bahan pertimbangan untuk membantu sekolah dalam membuat langkah-langkah yang bertujuan untuk menurunkan tingkat kenakalan siswa dengan cara meningkatkan tingkat keterlibatan siswa. Karena siswa yang terlibat pada aktifitas di sekolah dapat menurunkan tingkat kenakalan remaja.

Bagi peneliti selanjutnya, saat melakukan pengambilan data sebaiknya dilakukan secara langsung tanpa mengganggu jam pelajaran berlangsung atau pendamping dari pihak sekolah yang terkait. Diharapkan pada peneliti selanjutnya dapat secara langsung turun ke setiap proses pembelajaran yang ada disekolah dan lebih fleksibel untuk dapat langsung menentukan sampel yang sesuai dengan kriteria. Hal ini dapat digunakan untuk penambahan observasi terhadap variabel lainnya yang mungkin berkontribusi dalam penelitian ini serta menambah keakuratan data pada penelitian.

\section{REFERENSI}

Bakwin, H. (2015). Psychology aspects of pediatrics juvenile delinquency. New York University.

Bender, K. (2012). The mediating effect of school engagement in the relationship between youth maltreadment and juvenile delinquancy. Child and School. 43(1): 37-48.

Chapman. E. (2003). Alternative approach to assessing student engagement rates. Pratical Assessment, Research \& Evaluation. 8(13): 1-7.

Chingtam. T. (2015). Causes of juvenile delinuency in the higher secondary school students. Journal of Research \& Method in Education. 5(5): 20-24

Daigle, L, E., Cullen, F, T., Jhon, P, W. (2013). Gender differences in the predictors of juvenile delinquency. Youth Violence and Juvenile Justice. 5(3): 254-286.

Firmansyah, M, J. (2018). KPAI : Tawuran pelajar 2018 lebih tinggi dibanding tahun lalu.Metro.tempo.co. Diakses pada tanggal 3 April 2019. 20.30.

Fredricks J.A., Blumenfeld P.C., Paris A.H. (2004). School engagement: potential of the concept, state of the evidence. Review of Educational Research, 74(1):59-109. 
Juliani Dwi Putri, Indra Prapto Nugroho, Marisya Pratiwi Jurnal Bimbingan dan Konseling Ar-Rahman

Volume 5, Nomor 2, Tahun 2019

e-ISSN 2477-6300

Gilman, R., Huebner, E. S., Furlong, M. J. (2009). Handbook of positive psychology in schools. Routledge. New York.

Harris-McKoy, D., Cui, M. (2013). Parental control, adolescent delinquency, and young adult criminal behavior. J Child Fam Stud.22:836843.

Kartono, K. (2013). Patologi sosial II: Kenakalan remaja. Jakarta: Rajawali Press.

Kennedy, J. F. (1963). The future promise of any nation can be directly measured by the present prospects of its youth. Adolescence and Delinquency.

Murray, S., Mitchell, J., Gale, T., Edwards, J., Zyngier, D. (2014). Student disengagement from primary schooling: A riview of research and practice. A Report To Research CASS Foundation.

Nourollah, M., Fatemeh, M., Farhad, J. (2015) A study of factors affecting juvenile delinquency. Biomedical \& Pharmacology Journal. 8:25-30.

Papalia, D., \& Feldman, R. D. (2012). Menyelami perkembangan manusia. Edisi keduabelas. Jakarta: Salemba Humanika.

Reeve, J., \& Tseng, C. M. (2011). Agency as a fourth aspect of students' engagement during learning activities. Contemporary Educational Psychology. 36:257-267.

Sarwono, Sarlito. (2006). Psikologi remaja. Rajawali Pers, Jakarta.

Santrock. J. W. (2003). Adolescence. perkembangan remaja. Edisi keenam. Jakarta: Erlangga.

Santrock, J. W. (2012). Life span development. Perkembangan masa hidup. Edisi ketiga belas. Jakarta: Erlangga.

Sugiyono. (2016). Metode penelitian kuantitatif dan kualitatif. P\&D.Alfabeta, Bandung.

Toldson, I, A., Sutton, R, M., Fry Brown, R, L. (2012). Preventing delinquency and promoting academic succes among school-age african american males. Journal of African American. 3(1): 11-27.

Wang, M.T., \& Holcombe, R. (2010). Adolescents' perception of school environment, engagement, and academic achievement in middle school. Educational Research Journal, 47(3): 633-662.

Wang, M.T., \& Fredricks J.A. (2014). The reciprocal links between school engagement, youth problem behaviors, and school dropout during adolescence. Child Development. 85(2): 722737.

Dipublikasikan Oleh :

UPT Publikasi dan Pengelolaan Jurnal

Universitas Islam Kalimantan Muhammad Arsyad Al-Banjari Banjarmasin 